\title{
Determination of Spatiotemporal Variations in Heavy Metal Concentration through Orontes River
}

\author{
Ece Kılıç*, Mehmet Fatih Can \\ Department of Water Resources Management and Organization, Faculty of Marine Sciences and Technology, Iskenderun Technical \\ University, 31200 Hatay, Turkey
}

\section{A R T I C LE INFO}

\section{Research Articles}

Received 05 May 2017

Accepted 19 July 2017

Keywords:

Heavy Metal Pollution

Water Quality

Multivariate Statistics

Orontes River

*Corresponding Author:

E-mail: ece.kilic@iste.edu.tr

\begin{abstract}
A B S T R A C T
Water quality in surface waters is an important concern since it directly affects public health. Therefore, to provide adequate quality of water, monitoring studies have been conducted all around the world. In this study, multivariate statistical methods were used to understand the spatial and temporal changes in heavy metal concentration (including As, $\mathrm{Cd}, \mathrm{Cr}, \mathrm{Cu}, \mathrm{Fe}, \mathrm{Hg}, \mathrm{Mn}, \mathrm{Pb}, \mathrm{Zn}$ ) through Orontes River. Monitoring study results belonging to 5 different stations in Orontes River was obtained from State of Hydraulic Works and evaluated according to Box and Whisker plots, two-way PERMONAVA analysis and Mann-Kendall trend test. Results indicated that heavy metal concentrations has been increasing year by year. However, there is no significant spatial change in heavy metal concentration and rather homogenous distribution was observed through Orontes River. On the other hand, Iron $(\mathrm{Fe})$ concentration in river was seasonal depended with no significant trend.
\end{abstract}

Türk Tarım - Gıda Bilim ve Teknoloji Dergisi, 5(9): 1086-1093, 2017

Asi Nehri Boyunca Ağır Metal Konsantrasyonunun Mekansal ve Zamansal Değişiminin Belirlenmesi

M A K A L E B İ L G İ İ

AraştırmaMmakalesi

Geliş 05 Mayıs 2017

Kabul 19 Temmuz 2017

Anahtar Kelimeler: Ağır Metal Kirliliği

Su kalitesi

Çok değişkenli istatistik

Asi nehri

\section{Ö Z E T}

Yüzey sularındaki su kalitesi doğrudan halk sağlığını etkilediğinden önemli bir endişe kaynağıdır. Bu sebeple, yeterli kalitede su sağlamak amaciyla, bütün dünyada izleme çalışmaları yürütülmeye başlanmıştır. Bu çalışmada, Asi Nehri boyunca ağır metal konsantrasyonundaki (As, $\mathrm{Cd}, \mathrm{Cr}, \mathrm{Cu}, \mathrm{Fe}, \mathrm{Hg}, \mathrm{Mn}, \mathrm{Pb}, \mathrm{Zn}$ dâhil) mekânsal ve zamansal değişimleri anlamak için çok değişkenli istatistiksel yöntemler kullanılmıştır. Devlet $\mathrm{Su}$ İşleri tarafından Asi Nehri üzerinde izleme çalışması yürütülen 5 farklı istasyondan elde edilen izleme sonuçları Box-Whisker grafikleri, iki yönlü PERMONAVA testi ve MannKendall trend testi kullanılarak değerlendirilmiştir. Sonuçlar nehirdeki ağır metal konsantrasyonunun zamanla arttı̆̆ını fakat ağır metal değerlerinin istasyonlar arasında önemli ölçüde değişmediğini, daha ziyade homojen bir dağılım gösterdiğini, ortaya koymuştur. Öte yandan, nehirdeki Fe konsantrasyonu belirli bir trend olmaksızın mevsimsellik göstermektedir.

*Sorumlu Yazar:

E-mail: ece.kilic@iste.edu.tr 


\section{Introduction}

Surface waters have been used for agricultural, industrial and domestic purposes. In addition, they have been used as a carrying element for domestic and industrial discharges as well as run-off from agricultural sources (Singh et al., 2005; Chapra, 2008). Therefore, water quality in a surface water depends not only on natural processes (i.e. precipitation, erosion and weathering), but also anthropogenic activities (Giri and Singh, 2014). As a result, identification and quantification of pollution sources and protection of the quality of surface waters are crucial since adequate quality and quantity of water is essential for sustainable development (Bartram and Balance, 1996; Dević et al., 2016).

There are many concerns related to the quality of surface waters such as high organic content, low dissolved oxygen, high microbiological content, the existence of toxic materials and heavy metals. Among them, heavy metals are primary environmental polluters due to their durability, bioaccumulation, nonbiodegradability and toxicity potential to living beings (Yılmaz and Doğan, 2008; Dong et al., 2015). Some heavy metals are tolerable in low concentrations due to their bio-chemical functions; yet, they all become toxic in higher concentrations since they cause damage to the nervous system and internal organs (Liu et al., 2009; Förstner and Prosi, 2013).

Transport of heavy metals into surface waters could be due to different natural and anthropogenic activities. Major sources of heavy metals in surface waters are geological weathering, animal and human extraction, industrial processing of ores and metals, leaching from garbage and solid waste streams, disposal of untreated and partially treated effluents, metal chelates of different industries and use of heavy metal including fertilizer and pesticides in agriculture (Förstner and Prosi, 2013; Varol and Şen, 2012; Agca et al., 2014; Dević et al., 2016).

Even though there are many studies regarding with heavy metal concentration in surface waters worldwide (Ma et al., 2015; Zhaoyong et al., 2015; O'Neill et al., 2015; Dević et al., 2016), concentration of heavy metals in a surface water depends upon factors specific to that surface water like substrate sediment concentration, water chemistry, self-purification capacity of river system and anthropogenic activities taking place in the area (Förstner and Prosi, 2013; Islam et al., 2015). Therefore, monitoring and evaluating heavy metal concentrations in water bodies is a case-specific issue. Although different methodologies are employed for the evaluation of heavy metal concentration in literature (Verma and Gupta, 2015; Maanan et al., 2015; Tiwari et al., 2016), multivariate statistical methods become widely applied tools for these type of studies especially when huge and complex chemical data sets are of concern (Singh et al., 2005; Li et al., 2009; Dong et al., 2015; Varol, 2011). Also, the boxwhisker plot is used to identify basic statistical features of datasets through visual displays (Singh et al., 2005; Devic et al., 2015; Ogwueleka, 2015).

Orontes (Asi) River, is a transboundary river and its water is shared among Labuan, Syria and Turkey (Comair et al., 2015). After flowing through Turkish-Syrian border, it discharges into the Mediterranean Sea from Samandağ district of Hatay (Scheumann et al., 2011). River is mainly used for irrigational purposes since it is surrounded with very fertile agricultural land (UNESCOIHE, 2002). Also, nearly 200 industrial plants and hundreds of small size factories are located around or nearby the river and discharge their effluents causing a water pollution (Y1lmaz and Doğan, 2008). Even though there are some studies which evaluates heavy metal concentrations in Orontes River (Çalışkan, 2005; Yılmaz and Doğan, 2008), they are missing in terms of evaluation of seasonal and temporal variations of heavy metal concentrations. Since water quality in a basin is strongly depended on its unique features like climate, anthropogenic activities, geology, land use etc., this study will fill the gap in the literature and investigate the spatiotemporal change. The purpose of this study is to evaluate spatio-temporal changes of heavy metal concentration in Orontes River using 10- year data which was obtained from State Water Works of Turkey (SWW).

\section{Materials and Methods}

\section{Study Area}

The main tributary of Orontes River inside Turkish territory was evaluated in terms of heavy metal change in this study. Even though Orontes River is mainly used for agricultural purposes, agro-industry and heavy metal industry is started to develop in the study area (TUBITAK, 2013).

Water quality monitoring data which was obtained from SWW covering the year from 2004 to 2014 based on query pattern was evaluated. Nine different types of heavy metals (including As, $\mathrm{Cd}, \mathrm{Cr}, \mathrm{Cu}, \mathrm{Fe}, \mathrm{Hg}, \mathrm{Mn}, \mathrm{Pb}$ and $\mathrm{Zn}$ ) were monitored at different stations, seasonally (Figure 1). Unfortunately, measured heavy metals and their monitored time interval is different and there is no concurrence between each other. For example, only Fe was measured at Esrefiye station from 2010 to 2012. Even though all parameters were analyzed at the Antakya Station, most of the heavy metals were not measured at Esrefiye and Demirköprü stations (see Table 1). Therefore, since only $\mathrm{Fe}$ and $\mathrm{Mn}$ had qualified monitoring pattern and continuity, they were used to investigate temporal and spatial heavy metal concentration variation in Orontes river.

\section{Statistical Methods}

Box-Whisker plots, two-way PERMONAVA analysis and Mann-Kendall Trend Analysis were conducted to evaluate spatio-temporal change in heavy metal concentration. Box-Whisker plots were used to show mean values with their deviations by yearly and stationary. However, PERMANOVA and Mann-Kendall Trend analyses were applied only for $\mathrm{Fe}$ and $\mathrm{Mn}$ since they have consistent data. PERMANOVA is a nonparametric test of ANOVA and it was used to evaluate the statistical significances of mean values of $\mathrm{Fe}$ and $\mathrm{Mn}$ depending on station and season interaction. Also, in order to understand temporal changes of $\mathrm{Fe}$ and $\mathrm{Mn}$ through monitoring period, Mann-Kendall Trend analysis was conducted to determine time trends. Before applying any analysis, all data were checked to determine outliers and missing values by using scatter plots. For all data analyses, Microsoft Excel and PAST Software v.3.12 were used (Hammer et al., 2001). 
Table 1 Monitoring periods of heavy metals

\begin{tabular}{l|ccccc}
\hline \multicolumn{1}{c|}{ Parameter } & Eşrefiye & Demirköprü & Küçük Asi & Antakya & Samandağ \\
\hline $\mathrm{As}$ & $\mathrm{nm}$ & $2013-2014$ & $\mathrm{~nm}$ & $2008-2014$ & $2013-2014$ \\
$\mathrm{Cd}$ & $\mathrm{nm}$ & 2013 & $\mathrm{~nm}$ & 2004 & $2013-2014$ \\
$\mathrm{Cr}$ & $\mathrm{nm}$ & $2013-2014$ & $\mathrm{~nm}$ & $2004-2014$ & $2013-2014$ \\
$\mathrm{Cu}$ & $\mathrm{nm}$ & $2013-2014$ & $\mathrm{~nm}$ & $2004-2014$ & $2013-2014$ \\
$\mathrm{Fe}$ & $2010-2012$ & $2004-2014$ & $2004-2014$ & $2004-2014$ & $2010-2014$ \\
$\mathrm{Hg}$ & $\mathrm{nm}$ & 2013 & $\mathrm{~nm}$ & $2004-2009$ & $\mathrm{~nm}$ \\
$\mathrm{Mn}$ & $\mathrm{nm}$ & $2011-2014$ & $2011-2014$ & $2011-2014$ & $2011-2014$ \\
$\mathrm{~Pb}$ & $\mathrm{~nm}$ & $\mathrm{~nm}$ & $\mathrm{~nm}$ & $2004-2014$ & $2013-2014$ \\
$\mathrm{Zn}$ & $\mathrm{nm}$ & $2013-2014$ & $\mathrm{~nm}$ & $2004-2014$ & $2013-2014$ \\
\hline $\mathrm{nm}$ & & & & &
\end{tabular}

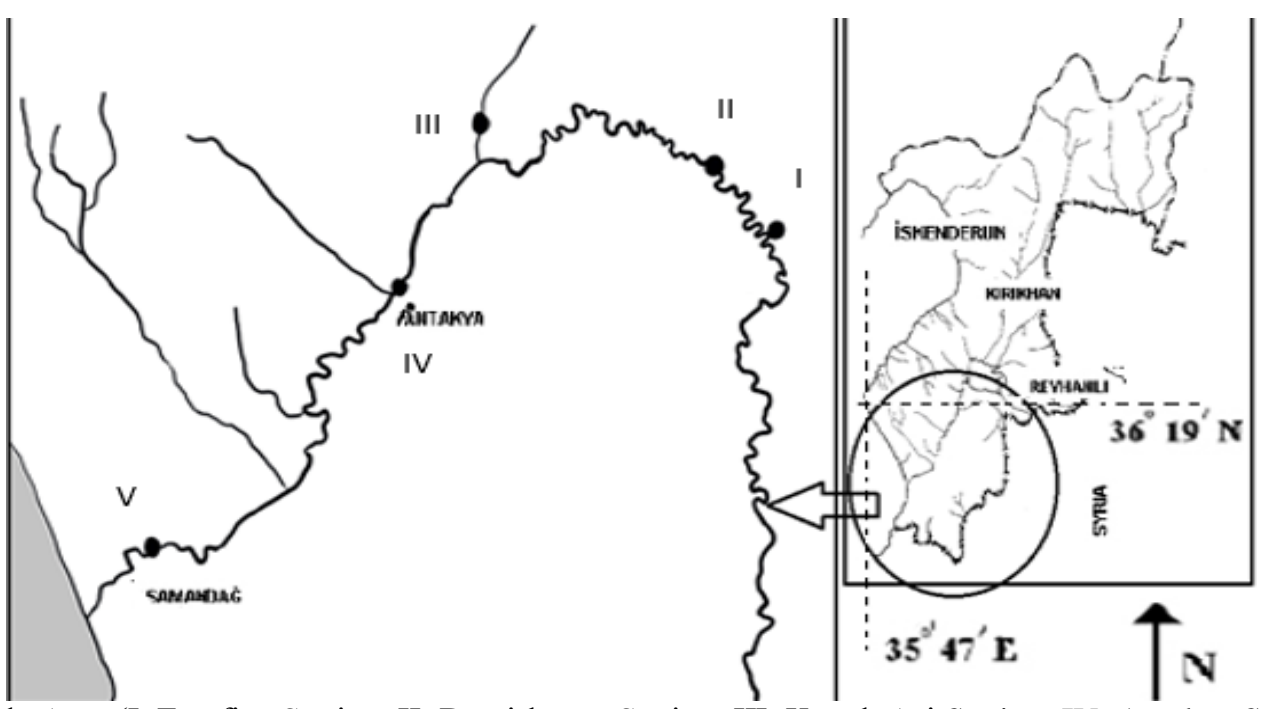

Fig 1 Study Area (I: Eşrefiye Station, II: Demirköprü Station, III: Küçük Asi Station; IV: Antakya Station; V: Samandağ Station)

\section{Results and Discussion}

\section{Basic Statistics of Heavy Metals}

Seasonal heavy metal monitoring results measured at five stations located at the main stream of Orontes River were taken from SWW. Descriptive statistics indicating the state of heavy metal pollution is given Table 2 . It is observed that most parameters especially $\mathrm{As}, \mathrm{Cr}, \mathrm{Cu}, \mathrm{Pb}$, $\mathrm{Zn}$ and $\mathrm{Mn}$ have a high standard deviation and a high change interval. This situation indicates that heavy metal concentration varies depending on anthropogenic and natural factors (González et al., 2014). Mean concentration of $\mathrm{Fe}, \mathrm{Mn}$ and $\mathrm{Zn}$ was chancing between 353-594 $\mu \mathrm{g} / \mathrm{L}, 63-353 \mu \mathrm{g} / \mathrm{L}$ and 30-50 $\mu \mathrm{g} / \mathrm{L}$, respectively. Thus, they are the most significant heavy metals through all stations.

Water quality levels of inland surface waters are regulated by water pollution control regulation (WPCR) in Turkey (Ministry of Environment, 2004). Inland surface waters are categorized into four main groups (Class-1 to Class-4) depending on its physical, chemical and biological standards. According to these standards, Orontes River categorized as Class-1 surface water for all parameters except $\mathrm{Fe}, \mathrm{Hg}$ and $\mathrm{Mn}$. According to $\mathrm{Fe}$ and Mn concentration, water quality in the river is chancing from Class-1 to Class-2 depending on the location. Similarly, it is Class 2 to Class 3 type of inland surface water with respect to $\mathrm{Hg}$ concentrations.

Mean concentration of heavy metals obtained in this study are similar to those obtained in Y1lmaz et al. (2008).
They also found that $\mathrm{Fe}, \mathrm{Mn}$ and $\mathrm{Zn}$ have much greater concentrations than other heavy metals. Additionally, mean concentrations of $\mathrm{Ag}, \mathrm{Cd}, \mathrm{Cu}, \mathrm{Ni}$ and $\mathrm{Pb}$ are similar. On the other hand, they reported that mean $\mathrm{Fe}$ and $\mathrm{Zn}$ concentration at 2004 were $98.8 \mu \mathrm{g} / \mathrm{L}$ and $39.0 \mu \mathrm{g} / \mathrm{L}$, respectively. Therefore, $\mathrm{Fe}$ and $\mathrm{Zn}$ concentrations in river were increasing within last decade. This could be due to establishment of small-scale iron steel industries near the river. Also, since Orontes river is a transboundary river, increase in $\mathrm{Fe}$ and $\mathrm{Zn}$ concentration could be due to Syrian civil war.

Agca et al. (2009), investigated spatial and temporal variation of some water quality parameters from October 2004 to November 2005.They reported mean $\mathrm{Zn}$ and Fe concentration during study period as $0.30 \mu \mathrm{g} / \mathrm{L}$ and 3.74 $\mu \mathrm{g} / \mathrm{L}$, respectively. Mean concentration of $\mathrm{Zn}$ and $\mathrm{Fe}$ during similar period was $18.3 \mu \mathrm{g} / \mathrm{L}$ and $115 \mu \mathrm{g} / \mathrm{L}$ according to SWW data. While these findings considered with Yilmaz et al (2008) study, there is drastic difference with Agca et al (2009) study. Difference in the results may arise from seasonal variations, methodological differences, temporal differences or combination of them.

Mutlu and Uncumusaoğlu (2016) investigated the temporal and spatial variation on some water quality parameters in Brook Kurucay. They found that minimum and maximum concentrations of heavy metals changed between $0.01-2.7 \mu \mathrm{g} / \mathrm{L}$ for $\mathrm{Fe}, 1-3.6 \mu \mathrm{g} / \mathrm{L}$ for $\mathrm{Cu}, 0.00-1.7$ $\mu \mathrm{g} / \mathrm{L}$ for $\mathrm{Cd}, 0.00-0.016 \mu \mathrm{g} / \mathrm{L}$ for $\mathrm{Hg}$ and $1.00-20 \mu \mathrm{g} / \mathrm{L}$ 
for $\mathrm{Zn}$. With the impact of human activities taking place along the flow direction of Brook, mainly agriculture and some mining activities, concentration of heavy metals have been increasing. Also, they found that mean concentrations of all heavy metals have been increasing during spring months and decreasing during summer months. During Autumn, mean Fe and $\mathrm{Zn}$ concentrations were decreasing, on the other hand, mean $\mathrm{Cu}, \mathrm{Cd}$ and $\mathrm{Hg}$ concentrations were continue to rise.

Davutluoglu et al. (2011) found low $\mathrm{Cd}, \mathrm{Cr}, \mathrm{Cu}, \mathrm{Fe}$, $\mathrm{Mn}, \mathrm{Pb}$ and $\mathrm{Zn}$ concentration in the Seyhan River which were varied between $0.0-0.064 \mathrm{mg} / \mathrm{L}, 0.001-0.004 \mathrm{mg} / \mathrm{L}$, 0.001-0.074 mg/L, $\quad 0.0-0.006 \mathrm{mg} / \mathrm{L}, \quad 0.001-0.009 \mathrm{mg} / \mathrm{L}$, $0.001-0.152 \mathrm{mg} / \mathrm{L}$ and $0.003-0.331 \mathrm{mg} / \mathrm{L}$, respectively. Mutlu and Kurnaz (2017) investigated the pollution status of Sakız Pond and they reported that annual mean concentration of $\mathrm{Fe}, \mathrm{Pb}, \mathrm{Cu}, \mathrm{Cd}, \mathrm{Hg}$ and $\mathrm{Zn}$ were $2 \mu \mathrm{g} / \mathrm{L}$, $0.98 \mu \mathrm{g} / \mathrm{L}, 5.50 \mu \mathrm{g} / \mathrm{L}, 0.34 \mu \mathrm{g} / \mathrm{L}, 0.005 \mu \mathrm{g} / \mathrm{L}, 2.69 \mu \mathrm{g} / \mathrm{L}$ and $12.36 \mu \mathrm{g} / \mathrm{L}$, respectively. Akbulut and Akbulut (2010) measured some metal concentrations in Kizılırmak
River Basin at February, May and Agust 2008. They reported that metal concentration varied between 0.0 and $377.9 \mu \mathrm{g} / \mathrm{L}$ for $\mathrm{Zn}, 0.0042$ and $20.44 \mu \mathrm{g} / \mathrm{L}$ for $\mathrm{Cr}, 0.0$ and $120.4 \mu \mathrm{g} / \mathrm{L}$ for $\mathrm{Cu}$ and $2.28-56.91 \mu \mathrm{g} / \mathrm{L}$ for $\mathrm{Pb}$. Wide range of variation indicates that heavy metal concentration varies seasonally and spatially. Varol and Şen (2012) found that heavy metal contamination in he Tigris river is mainly resulting from copper mining activities and maximum observed $\mathrm{As}, \mathrm{Cd}, \mathrm{Cr}, \mathrm{Cu}, \mathrm{Fe}, \mathrm{Mn}$, $\mathrm{Pb}$ and $\mathrm{Zn}$ concentration are $2.354 \mu \mathrm{g} / \mathrm{L}, 1.368 \mu \mathrm{g} / \mathrm{L},<5$ $\mu \mathrm{g} / \mathrm{L}, 165 \mu \mathrm{g} / \mathrm{L}, 388 \mu \mathrm{g} / \mathrm{L}, 467 \mu \mathrm{g} / \mathrm{L}, 0.342 \mu \mathrm{g} / \mathrm{L}$ and 37.0 $\mu \mathrm{g} / \mathrm{L}$, respectively. Kurnaz et al. (2016) investigated heavy metal content in surface water of Çigdem Pond. According to these study, annual mean concentration of $\mathrm{Fe}, \mathrm{Pb}, \mathrm{Cu}, \mathrm{Cd}, \mathrm{Hg}, \mathrm{Zn}$ was reported as $2 \mu \mathrm{g} / \mathrm{L}, 1.02$ $\mu \mathrm{g} / \mathrm{L}, 6.75 \mu \mathrm{g} / \mathrm{L}, 0.28 \mu \mathrm{g} / \mathrm{L}, 0.006 \mu \mathrm{g} / \mathrm{L}$ and $10.36 \mu \mathrm{g} / \mathrm{L}$, respectively. They believed that existence of heavy metals in the pond strongly correlated with agricultural activity like excessive usage of fertilizers, pruning in fruit gardens.

Table 2 Descriptive statistic for heavy metals

\begin{tabular}{|c|c|c|c|c|c|c|}
\hline \multirow{2}{*}{\multicolumn{2}{|c|}{ Parameter $(\mu \mathrm{g} / \mathrm{L})$}} & \multicolumn{5}{|c|}{ Stations } \\
\hline & & Antakya & Demirköprü & Küçük Asi & Samandağ & Eşrefiye \\
\hline \multirow{4}{*}{ As } & Min & 0.37 & 0.79 & $\mathrm{~nm}$ & 1.57 & $\mathrm{~nm}$ \\
\hline & $\operatorname{Max}$ & 2.87 & 2.09 & $\mathrm{~nm}$ & 2.32 & $\mathrm{~nm}$ \\
\hline & Mean & 1.94 & 1.45 & $\mathrm{~nm}$ & 2.12 & $\mathrm{~nm}$ \\
\hline & St.Dev. & 0.989 & 0.54 & $\mathrm{~nm}$ & 0.36 & $\mathrm{~nm}$ \\
\hline \multirow{4}{*}{$\mathrm{Cd}$} & Min & 0 & 0.03 & $\mathrm{~nm}$ & 0.06 & $\mathrm{~nm}$ \\
\hline & Max & 0.01 & 0.08 & $\mathrm{~nm}$ & 0.16 & $\mathrm{~nm}$ \\
\hline & Mean & 0.002 & 0.06 & $\mathrm{~nm}$ & 0.11 & $\mathrm{~nm}$ \\
\hline & St.Dev. & 0.005 & 0.04 & $\mathrm{~nm}$ & 0.04 & $\mathrm{~nm}$ \\
\hline \multirow{4}{*}{$\mathrm{Cr}$} & Min & 1.46 & 2.01 & $\mathrm{~nm}$ & 3.25 & $\mathrm{~nm}$ \\
\hline & Max & 12.5 & 2.98 & $\mathrm{~nm}$ & 20.88 & $\mathrm{~nm}$ \\
\hline & Mean & 6.09 & 2.56 & $\mathrm{~nm}$ & 8.53 & $\mathrm{~nm}$ \\
\hline & St.Dev. & 4.010 & 0.50 & $\mathrm{~nm}$ & 8.28 & $\mathrm{~nm}$ \\
\hline \multirow{4}{*}{$\mathrm{Cu}$} & Min & 3.74 & 2.09 & $\mathrm{~nm}$ & 3.25 & $\mathrm{~nm}$ \\
\hline & Max & 20.19 & 8.17 & $\mathrm{~nm}$ & 20.88 & $\mathrm{~nm}$ \\
\hline & Mean & 9.26 & 4.28 & $\mathrm{~nm}$ & 8.53 & $\mathrm{~nm}$ \\
\hline & St.Dev. & 6.06 & 2.70 & $\mathrm{~nm}$ & 8.28 & $\mathrm{~nm}$ \\
\hline \multirow{4}{*}{$\mathrm{Fe}$} & Min & 25 & 90.00 & 15.00 & 30.00 & 10.00 \\
\hline & Max & 1765.4 & 1507.00 & 1413.20 & 1512.10 & 950.00 \\
\hline & Mean & 353.3 & 408.94 & 361.02 & 594.61 & 437.88 \\
\hline & St.Dev. & 435.348 & 393.54 & 396.05 & 441.96 & 370.53 \\
\hline \multirow{4}{*}{$\mathrm{Hg}$} & Min & 0.3 & 0.89 & $\mathrm{~nm}$ & $\mathrm{~nm}$ & $\mathrm{~nm}$ \\
\hline & Max & 0.5 & 0.89 & $\mathrm{~nm}$ & $\mathrm{~nm}$ & $\mathrm{~nm}$ \\
\hline & Mean & 0.433333 & 0.89 & $\mathrm{~nm}$ & $\mathrm{~nm}$ & $\mathrm{~nm}$ \\
\hline & St.Dev. & 0.11547 & - & $\mathrm{nm}$ & $\mathrm{nm}$ & $\mathrm{nm}$ \\
\hline \multirow{4}{*}{$\mathrm{Mn}$} & Min & 27 & 13.00 & 33.00 & 25.00 & $\mathrm{~nm}$ \\
\hline & Max & 147 & 328.00 & 1555.00 & 131.00 & $\mathrm{~nm}$ \\
\hline & Mean & 78.44 & 68.80 & 353.67 & 63.33 & $\mathrm{~nm}$ \\
\hline & St.Dev. & 39.59 & 93.72 & 558.01 & 32.14 & $\mathrm{~nm}$ \\
\hline \multirow{4}{*}{$\mathrm{Pb}$} & Min & 0.3 & $\mathrm{~nm}$ & $\mathrm{~nm}$ & 0.70 & $\mathrm{~nm}$ \\
\hline & Max & 3.3 & $\mathrm{~nm}$ & $\mathrm{~nm}$ & 2.00 & $\mathrm{~nm}$ \\
\hline & Mean & 1.38 & $\mathrm{~nm}$ & $\mathrm{~nm}$ & 1.43 & $\mathrm{~nm}$ \\
\hline & St.Dev. & 1.18617 & $\mathrm{~nm}$ & $\mathrm{~nm}$ & 0.56 & $\mathrm{~nm}$ \\
\hline \multirow{4}{*}{$\mathrm{Zn}$} & Min & 7.03 & 23.50 & $\mathrm{~nm}$ & 23.80 & $\mathrm{~nm}$ \\
\hline & Max & 87.6 & 77.30 & $\mathrm{~nm}$ & 76.30 & $\mathrm{~nm}$ \\
\hline & Mean & 30.75 & 50.05 & $\mathrm{~nm}$ & 48.43 & $\mathrm{~nm}$ \\
\hline & St.Dev. & 28.75 & 22.66 & $\mathrm{~nm}$ & 27.67 & $\mathrm{~nm}$ \\
\hline
\end{tabular}



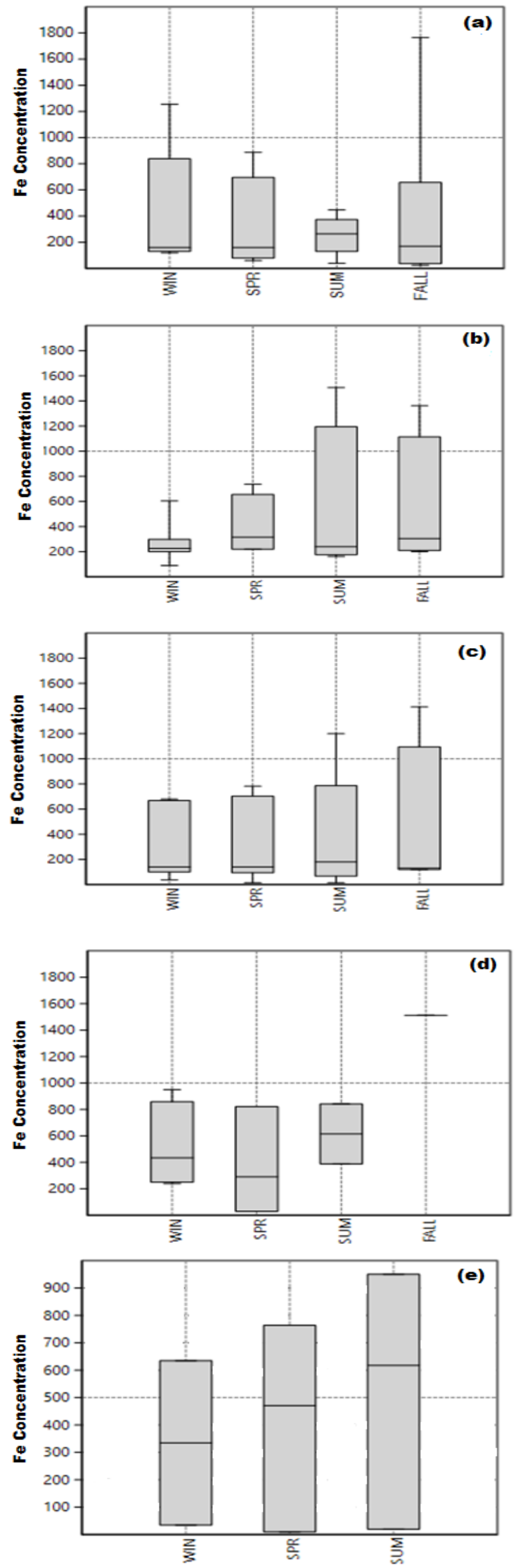

Fig 2 Temporal variations in Fe concentration at (a) Antakya, (b) Demirköprü, (c) Küçük Asi, (d) Samandağ, (e) Eşrefiye Stations (Scales are different)
In summary, water quality in Orontes River is in good quality for $\mathrm{As}, \mathrm{Cd}, \mathrm{Cr}, \mathrm{Cu}, \mathrm{Pb}$ and $\mathrm{Zn}$. Additionally, $\mathrm{Fe}$, $\mathrm{Hg}$ and $\mathrm{Mn}$ are the most significant heavy metals in study area in terms of pollution indices. It is also noticeable that heavy metal concentration in the river has been increasing day by day. This increase is mainly result of human derived factors. Water coming from Syrian border is heavily polluted with the residuals of civil war. Additionally, industrial discharges from iron- steel processing facilities increase the pollution level of the river. Even though, surface flow originated in rainy seasons may help to dilute the system, self-purification capacity of river is not capable of handling this pollution load. Therefore, elimination of industrial discharges into river should be prevented and remediation studies near the border should be considered for the enhancement of water quality in Orontes river.

\section{Temporal Variations}

Since As, $\mathrm{Cd}, \mathrm{Cr}, \mathrm{Cu}, \mathrm{Hg}, \mathrm{Pb}, \mathrm{Zn}$ concentrations in Orontes river were monitored seasonally from 2013 to 2014 at 3 different stations, data was incapable for determination of spatial-temporal changes and trend analysis. Therefore, spatial and temporal variation of Fe and $\mathrm{Mn}$ investigated using multivariate statistics.

Box-Whisker plots which indicate the temporal variations of $\mathrm{Fe}$ concentration depending on stations are given in Figure 2. They indicate that mean Fe concentration was observed during summer season at all stations. This could be due to the excessive evaporation observed during summer. Also, Fe concentration decreases in rainy seasons causing high variability in the data especially in Antakya and Küçük Asi stations. Surface runoff coming from Amik Plain could cause a dilution and could explain the variation in $\mathrm{Fe}$ concentration at upcoming stations.

PERMONAVA test is carried out to further investigate temporal change in Orontes River. Similar to Box-Whisker plots, PERMONAVA test also indicated that $\mathrm{Fe}$ concentration in river is changing seasonally $(\mathrm{P} \leq 0.05)$. This means that $\mathrm{Fe}$ concentration is depended natural factors like precipitation, surface runoff, evaporation. In other words, Fe concentration is related with the climate of the region.

Even though PERMONAVA test is useful tool in determination of seasonality, it does not provide any insight related with the existence of trends. Therefore, non-parametric Mann-Kendall trend analysis is conducted to evaluate existence of any regular increase or decrease in the $\mathrm{Fe}$ concentration. It showed that there is no significant trend in $\mathrm{Fe}$ concentrations with $\mathrm{P} \geq 0.05$. Therefore, although Fe concentration in the river has been increasing according to mean concentrations; it did not show any statistically meaningful increasing trend.

Results of PERMOVA and Mann-Kendall test indicates that climatic factors help river to handle with $\mathrm{Fe}$ load coming from anthropogenic activities. Especially wet seasons when precipitation abundant, surface runoff cause a dilution and decrease the pollution load of river. 

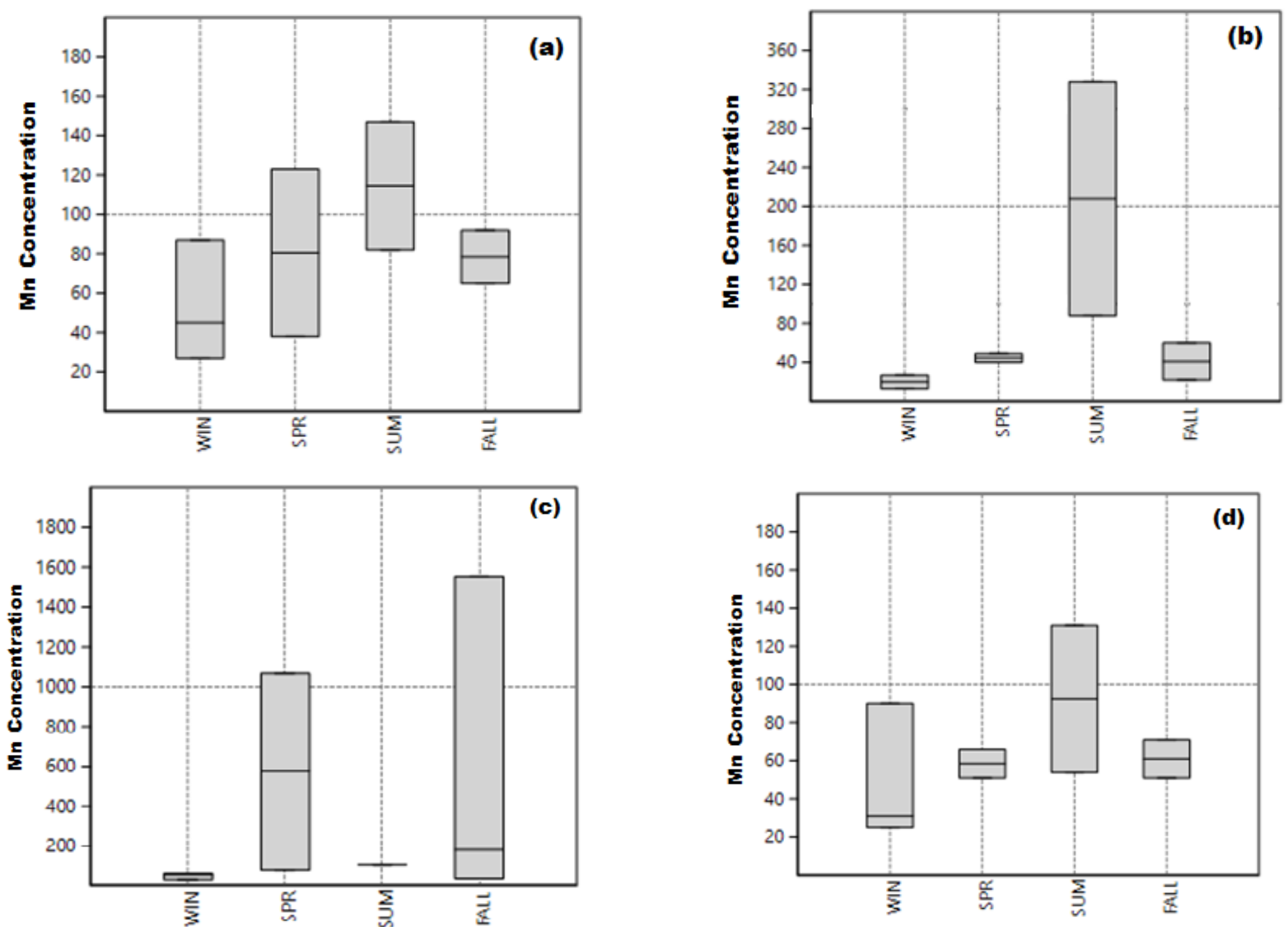

Fig 3 Temporal variations in Mn concentration at (a) Antakya, (b) Demirköprü, (c) Küçük Asi, (d) Samandağ Stations
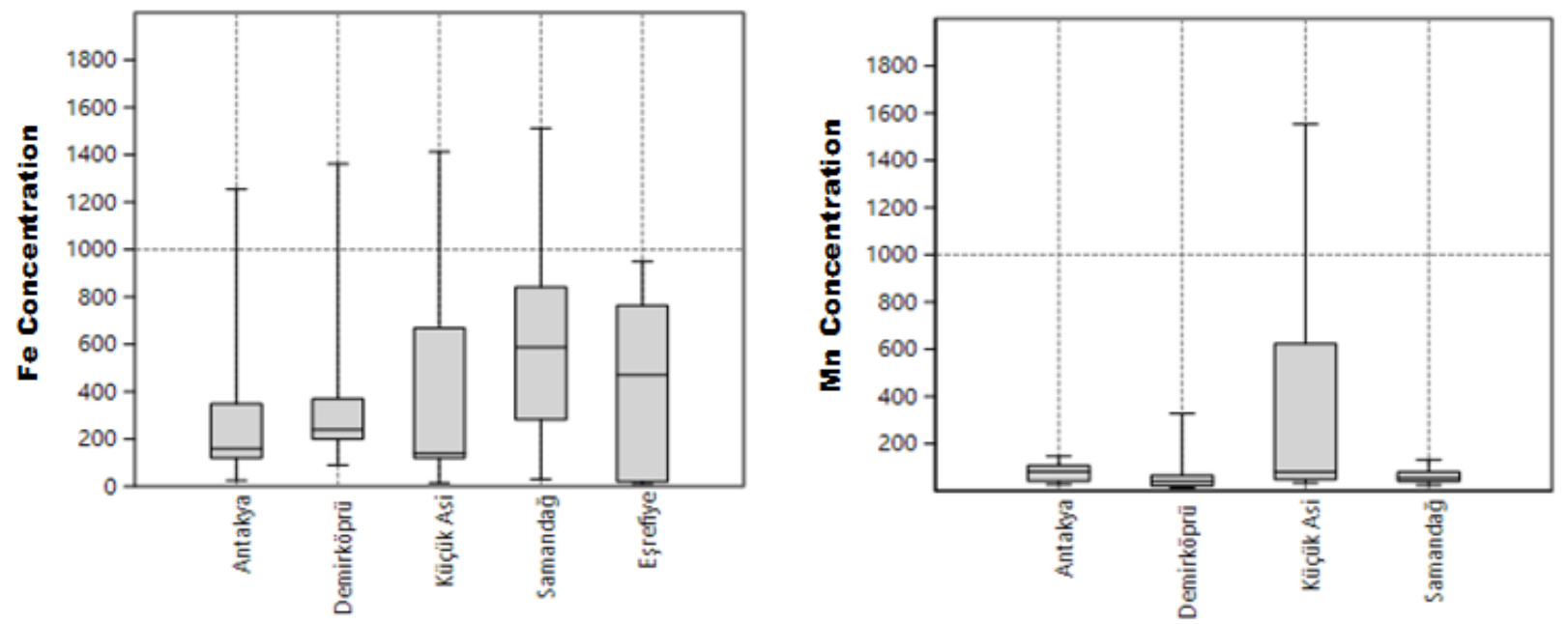

Fig 4 Spatial variations in $\mathrm{Fe}$ (on the right) and $\mathrm{Mn}$ (on the left) concentration

Box-Whisker plots which indicate the temporal variations of Mn concentration depending on stations is given in Figure 3. Mean Mn concentration in Orontes River was greater at dry season compared to wet seasons. Ödemiş et al (2007), demonstrated that river is greatly affected by rainfall and its flowrate increase by $30 \%$ during wet seasons. Therefore, it is reasonable to believe that rainfall is the main reason in decreasing trend at $\mathrm{Mn}$ concentrations. However, PERMONAVA test indicated that variation in $\mathrm{Mn}$ concentration is seasonally independent $(\mathrm{P} \geq 0.05)$. Therefore, it can be concluded that even though climatic conditions like precipitation and rainfall should have impact on concentrations, they are not main factors affecting temporal change in $\mathrm{Mn}$ concentrations. As a result, other factors like geological conditions, water purification capacity and geological weathering could play have a great role on $\mathrm{Mn}$ concentration.

\section{Spatial Variations}

Box-Whisker plot which indicates the spatial variations of $\mathrm{Fe}$ and $\mathrm{Mn}$ concentration depending on stations is given in Figure 4. According to Box-Whisker plot, mean $\mathrm{Fe}$ concentration in Samandağ station is highest and followed by Eşrefiye, Demirköprü, Antakya and Küçük Asi stations, respectively. Small industrial 
area located near the Samandağ station could be the reason of high Fe concentration observed in the area. On the contrary, Mn concentration through stations was smooth.

Similar to temporal variations, two way PERMONAVA test is conducted to understand spatial variation in $\mathrm{Fe}, \mathrm{Mn}$ concentration. Results showed that both $\mathrm{Fe}$ and $\mathrm{Mn}$ concentration distribution are homogenous and there is no change depending on station $(\mathrm{P} \geq 0.05)$. Agca et al. found similar findings regarding on the spatial distribution of Fe and $\mathrm{Mn}$ in Orontes River.

Monitoring stations expected to reflect different anthropogenic activities taking place in the basin. Esrefiye station is important since it is near the surian border. So, it expected to indicate upcoming water quality. Küçük Asi, Demirköprü and Samandağ stations are expected to indicate effect of agricultural activities since main anthropogenic activity taking place is agriculture at the area. Antakya station is expected to indicate domestic and industrial discharges since it is close to urbanized and industrialized area. However, result of PERMONAVA test indicate that there were no statistically valuable change in the $\mathrm{Fe}$ and $\mathrm{Mn}$ concentration variation. Therefore, it is logical to assume that temporal variation in $\mathrm{Fe}$ and $\mathrm{Mn}$ concentration does not depend on land use and anthropogenic activities significantly.

\section{Conclusion}

This study is conducted to evaluate the spatial and temporal in heavy metal concentration in Orontes river. Study revealed that water quality is in good status for most of the heavy metals according to water pollution control regulation and $\mathrm{Fe}, \mathrm{Mn}$ and $\mathrm{Hg}$ main pollution indicating heavy metals in the area. Two-way PERMONAVA test indicated that even though seasonal variation affects the $\mathrm{Fe}$ concentration, there were no statistically important variation between stations. On the other hand, Mn concentration in the river is found as both temporally and spatially independent. Results indicate that natural factors like climate, precipitation, geological weathering, animal and human extraction are important mechanisms which help river to handle pollution load coming from human derived factors. Therefore, in order to improve water quality, direct discharge of wastewater from industrial and urbanized areas needs to be prevented by the establishment of wastewater treatment facilities. Also, it is important to note that heavy metal concentration in the river did not monitored properly and more comprehensive and detailed monitoring studies needs to be conducted.

\section{Acknowledgements}

It is a necessity to thank Assistant Professor Dr. Nebil YÜCEL for his supports in this study. This study is conducted with the support of Mustafa Kemal University, coordination of scientific research projects in the framework of project number 14781 .

\section{References}

Ağca N, Karanlık S, Ödemiş B. 2014. Assessment of ammonium, nitrate, phosphate, and heavy metal pollution in groundwater from Amik Plain, southern Turkey. Environmental monitoring and assessment., 186(9): 59215934.

Ağca N, Ödemiş B, Yalçin M. 2009. Spatial and temporal variations of water quality parameters in Orontes river (Hatay, Turkey). Fresenius Environmental Bulletin., 18(4): 456-460.

Akbulut, A, Akbulut, NE. 2010. The study of heavy metal pollution and accumulation in water, sediment, and fish tissue in Kızılırmak River Basin in Turkey. Environmental monitoring and assessment., 167(1): 521-526.

Bartram J, Ballance R. (Eds.). 1996. Water quality monitoring: a practical guide to the design and implementation of freshwater quality studies and monitoring programmes. CRC Press. pp6

Çalışkan E. 2005. Asi nehrinde su, sediment ve karabatak (balık) ağır metal değerlerinin araştırılması, Mustafa Kemal University, Science Institute, Hatay.

Çevre ve Orman Bakanlığı. Su Kirliliği Kontrolü Yönetmeliği. Resmi Gazete Sayıs1: 25687, 2004

Chapra SC. 2008. Surface water-quality modeling. Waveland press, pp. 30

Comair G, Eaton D, McKinney D. 2015. Water resources and security challenges in the Orontes river Basin. Science diplomacy and transboundary water management: the Orontes River case. In: Ballabio R, Comair FG, Scalet M., Scoullos M. (Editors). Science diplomacy and transboundary water management: The Orontes River case. Venice,Italy pp $125-137$

Davutluoglu OI, Seckin G, Ersu CB, Yilmaz T, Sari B. (2011). Assessment of metal pollution in water and surface sediments of the Seyhan River, Turkey, using different indexes. CLEAN-Soil, Air, Water, 39(2): 185-194.

Devic G, Djordjevic D, Sakan S. 2014. Natural and anthropogenic factors affecting the groundwater quality in Serbia. Sci Total Environ., 468: 933-942

Dević G, Sakan S, Đorđević D. 2016. Assessment of the environmental significance of nutrients and heavy metal pollution in the river network of Serbia. Environmental Science and Pollution Research., 23(1): 282-297.

Dong D, Liu X, Guo Z, Hua X, Su Y, Liang D. 2015. Seasonal and Spatial Variations of Heavy Metal Pollution in Water and Sediments of China's Tiaozi River. Polish Journal of Environmental Studies., 24(6): 2371-2379.

Förstner U, Prosi F. 2013. Heavy metal pollution in freshwater ecosystems. Biological Aspects of Freshwater Pollution: Proceedings of the Course Held at the Joint Research Centre of the Commission of the European Communities, Ispra, Italy, 5-9 June. pp 129-138

Giri S, Singh AK. 2014. Risk assessment, statistical source identification and seasonal fluctuation of dissolved metals in the Subarnarekha River, India. Journal of hazardous materials 265: 305-314.

González SO, Almeida CA, Calderón M, Mallea MA, González P. 2014. Assessment of the water self-purification capacity on a river affected by organic pollution: application of chemometrics in spatial and temporal variations. Environmental Science and Pollution Research., 21(18): 10583-10593

Hammer Ø, Harper DAT, Ryan PD. 2001. PAST: Paleontological Statistics Software Package for Education and Data Analysis. Palaeontologia Electronica., 4(1): 9pp.

Islam MS, Ahmed MK, Raknuzzaman M, Habibullah-AlMamun M, Islam MK. 2015. Heavy metal pollution in surface water and sediment: a preliminary assessment of an urban river in a developing country. Ecological Indicators., 48: 282-291. 
Kılıç E. 2007. Evaluation of water quality in Asi Watershed using multivariate statistics. İskenderun Technical University. Institute of Engineering and Natural Sciences, Hatay

Kurnaz A, Mutlu E, Uncumusaoğlu AA. 2016. Determination of water quality parameters and heavy metal content in surface water of Çiğdem Pond (Kastamonu/Turkey). Turkish Journal of Agriculture-Food Science and Technology, 4(10): 907-913.

Li S, Liu W, Gu S, Cheng X, Xu Z, Zhang Q. 2009. Spatiotemporal dynamics of nutrients in the upper Han River basin, China. J Hazard Mater., 162:1340-1346

Ma Y, Qin Y, Zheng B, Zhang L, Zhao Y. 2015. Seasonal variation of enrichment, accumulation and sources of heavy metals in suspended particulate matter and surface sediments in the Daliao River and Daliao River estuary, Northeast China. Environmental Earth Sciences., 73(9): 5107-5117.

Maanan M, Saddik M, Maanan M, Chaibi M, Assobhei O, Zourarah B. 2015. Environmental and ecological risk assessment of heavy metals in sediments of Nador lagoon, Morocco. Ecological Indicators., 48: 616-626.

Mutlu E, Kurnaz A. 2017. Determination of seasonal variations of heavy metals and physicochemical parameters in Sakiz Pond (Kastamonu-Turkey). Fresenius Environmental Bulletin, 26(4): 2806-2815.

Mutlu E, Uncumusaoğlu AA. 2016. Physicochemical Analysis of Water Quality of Brook Kuruçay. Turkish Journal of Agriculture - Food Science and Technology, 4(11): 991-998

Odemis B, Sangun MK, Buyuktas D. 2007. Temporal variations in water quantity and quality of Orontes River, Turkey. Asian Journal of Chemistry., 19(1): 711-723

Ogwueleka TC. 2015. Use of multivariate statistical techniques for the evaluation of temporal and spatial variations in water quality of the Kaduna River, Nigeria. Environmental monitoring and assessment., 187 (3): 1-17.

O'Neill A, Phillips DH, Bowen J, Gupta BS. 2015. Contaminants in surface water and sediments near the Tynagh silver mine site, County Galway, Ireland. Science of the Total Environment., 512: 261-272.
Scheumann W, Sagsen I, Tereci E. 2011. Orontes River Basin: Downstream Challenges and Prospects for Cooperation. In: Kibaroğlu A, Scheumann W, Kramer A. (Editors). Turkey's Water Policy: National Frameworks and International cooperation. Berlin: Springer, 2011: 301-312

Singh KP, Malik A, Sinha S. 2005. Water quality assessment and apportionment of pollution sources of Gomti river (India) using multivariate statistical techniques-a case study. Analytica Chimica Acta., 538 (1): 355-374.

Tiwari AK, Singh PK, Singh AK, De Maio M. 2016. Estimation of heavy metal contamination in groundwater and development of a heavy metal pollution index by using GIS technique. Bulletin of environmental contamination and toxicology., 96(4): 508-515.

TÜBİTAK. 2013. Havza Koruma Eylem Planlarının Hazırlanması :Asi Havzası Raporu, Türkiye Bilimsel ve Teknik Araştırma Kurumu Marmara Araştırma Merkezi Çevre Enstitüsü

UNESCO-IHE (Institute for water education). 2002. From conflict to cooperation in international water resources management: challenges and opportunities. Available at: http://unesdoc.unesco.org/images/0013/001354/135494e.pdf

Varol M. 2011. Assessment of heavy metal contamination in sediments of the Tigris River (Turkey) using pollution indices and multivariate statistical techniques. Journal of Hazardous Materials., 195: 355-364.

Varol M., Şen B. 2012 Assessment of nutrient and heavy metal contamination in surface water and sediments of the upper Tigris River, Turkey. Catena., 92: 1-10.

Verma R, Gupta BD. 2015. Detection of heavy metal ions in contaminated water by surface plasmon resonance based optical fibre sensor using conducting polymer and chitosan. Food chemistry., 166: 568-575.

Yilmaz AB, Doğan M. 2008. Heavy metals in water and in tissues of himri (Carasobarbus luteus) from Orontes (Asi) River, Turkey. Environmental monitoring and assessment. 144(1-3): 437-444.

Zhaoyong Z, Abuduwaili J, Fengqing J. 2015. Heavy metal contamination, sources, and pollution assessment of surface water in the Tianshan Mountains of China. Environmental monitoring and assessment., 187(2): 1-13. 